DOI https://doi.org/10.32837/app.v63i0.4

УДК $378+655.411$

Дубовик В. Б.

\title{
ПОЛІТИЧНІ І МІЖНАРОДНО-ПРАВОВІ ЕТАПИ ІСТОРІЇ СТАНОВЛЕННЯ ОБСС
}

\section{POLITICAL AND INTERNATIONAL LEGAL STAGES OF THE OSCE HISTORY}

*Viktor Dubovyk - PhD in Law.

\section{Abstract}

The article is devoted to the study of the history of the Organization for Security and Co-operation in Europe (OSCE) in historical, political, diplomatic, and international legal aspects. The history of the OSCE's emergence in the combination of these aspects becomes harmonious and understandable. It is impossible to examine the international legal aspects in isolation from the diplomatic ones since OSCE by its nature continues to exist as a unification of states with an indefinitely clear international legal status. The OSCE at the present stage comes from a Pan-European diplomatic conference - the CSCE, which has become a permanent feature over time. Gradually, it changed its name and expanded its existing response and management mechanisms, but failed to achieve international intergovernmental status.

The reasons for this are explored in our article. In turn, the following stages can be distinguished in the history of the CSCE / OSCE formation: 1. The formation of the OSCE from the preparatory conference to the Helsinki Final Act. 2. The existence of the CSCE as a permanent international conference. 3. Change of name to OSCE and gradual development of the institutional structure. 4. Attempts to endow the OSCE with international legal personality.

Keywords: Organization for Security and Co-operation in Europe, Law of International Organizations, International Conferences, International Treaty, USA.

Дослідження проблематика історії створення Організації з безпеки і співробітництва в Європі (ОБСЄ) має важливе значення для аналізу подальшого розвитку цього міжнародного утворення, вказуючи на допущені помилки, і визначаючи подальші перспективи. 
Особливо важлива ця проблематика для України, на території якої неодноразово створювалися місії ОБСЄ. Статус цих місій відзначав поступову еволюцію ОБСС.

Сама історія ОБСЄ і загалом міжнародно-правові питання існування цього утворення неодноразово ставали предметом наукового дослідження. Так, теоретичну основу нашого дослідження склали роботи У.А. Мансурова, С.С. Новікова, А.О. Віноградової, М.В. Жданкіна, Л.С. Айманбетової, І.Ю. Пишперової, Ю.А. Ясносокирського, В.А. Местнікова, С.П. Кубієвича, Г.Н. Макарової, М.П. Рея, Х. Нюньліст, Ф. Росіна, та інших.

Вперше пропозиція проведення загальноєвропейської конференції з безпеки по завершенні Другої світової війни надійшла від міністра закордонних справ Радянського Союзу В.М. Молотова в 1954 р. Зі скликанням загальноєвропейської конференції з безпеки СРСР хотів укласти сурогатний мирний договір, який формально завершив би Другу світову війну. При цьому Захід визнав би післявоєнні кордони Європи, включаючи розділену Німеччину, тим самим також прийнявши радянське переважання в Центральній та Східній Європі (Rey, 2008, p. 65-81). Тоді ця ініціатива була відкинута Заходом. Знов вона почала набирати обертів лише в 1969 р., коли Фінляндія запропонувала провести підготовчі переговори, які ведуть до такої конференції. Сприяли процесу проведення конференції також укладання двосторонніх угод з визнанням повоєнних кордонів укладених в центральній Свропі на початку 1970-х років.

Підготовчі переговори з проведення Наради з безпеки і співробітництва в Свропі (НБСС) розпочалися в передмісті Гельсінкі в 1972 р. (там керівники міністерств закордонних справ схвалили «Завершальні рекомендації консультацій в Гельсінкі» 3 позиціями своїх країн) і завершилися в Женеві у 1975 р. (тут делеговані державами експерти узгоджували спільні рішення за всіма пунктами порядку денного конференції). В їхній основі було закладено вже дещо інші підходи ніж це було в 1954 р. Країни Заходу поставили вимогу поєднати поняття безпеки з такими принципами, як самовизначення та особисті права людини. В підсумку радянський блок погодився на критичні для себе поступки в сфері захисту прав людини, а країни Заходу визнали територіальний статус-кво в Свропі. В той же час обидві сторони намагалися ошукати одна одну - СРСР не збирався на практиці поважати права людини, а країни Заходу відзначали, що беруть на себе лише політичні зобов'язання і не збираються на практиці виконувати безпековий 
компонент домовленості. Загальний скепсис висловив швейцарський дипломат Е. Талманн: «Як тільки чорнила підсохнуть на підписах у Гельсінкі, вся угода піде у забуття» (Nünlist, 2008, p. 213).

Незважаючи на таку критику і скепсис 30 липня - 1 серпня 1975 р. в Гельсінкі пройшла сама конференція на вищому рівні - Нарада з безпеки і співробітництва в Європі. На ній були представлені 31 держава Європи, окрім Албанії та США і Канада. Передбачалося, що держави будуть представляти голови держав чи урядів, але на практиці відбулося дещо по іншому. Наприклад, СРСР представляв керівник правлячої партії - Л. Брежнєв - керівник держави де факто, а не формальний голова держави.

На початкових етапах Гельсінського процесу (1972-1975 рр.) увага зосереджувалася на знаменитих «трьох кошиках», або трьох вимірах безпеки: I) військово-політичний, II) економічний і екологічний та III) людський. Проте, саме багато в чому забутий «четвертий кошик», перетворив початкову Гельсінську конференцію в квазіпостійний Гельсінкський процес. IV кошик стосувався питання про будь-які «зустрічі з подальшої роботи» НБСС. Від початку ініціатором надання постійно діючих функцій конференції, включаючи створення секретаріату був СРСР і ці ідеї спочатку зустрічали опор західних країн. Проте, спочатку, в 1974 р. нейтральні країни, такі як Фінляндія та Швейцарія, а потім і інші, почали підтримувати ідею подальших конференцій. Незважаючи на те, що вони все ще дуже вагалися, щоб не створити інструмент, за допомогою якого СРСР міг би нав' язати свою волю Західній Європі, нейтральні держави зрозуміли, що продовження засідань НБСЄ буде також важливим форумом для впливу на дебати з прав людини у Східному блоці. Більше того, вважалося, що такий форум також може бути використаний для того, щоб допомогти східноєвропейським сателітам Москви отримати більшу автономію від Радянського Союзу. Інноваційні особливості, включаючи активізацію людських контактів, покращення розповсюдження інформації та створення військових кодексів поведінки, можуть бути реалізовані та вдосконалені лише тоді, коли НБСЄ продовжить своє функціонування після 1975 р. (Rosin, 2014, p 119).

Вони вважали, що Гельсінський Заключний Акт матиме вигоду від подальшого процесу, який підкреслює майбутній напрямок нового, всеосяжного підходу до безпеки. Через те, що західні країни залишалися скептичними, нейтральні держави лише лобіювали регулярні наступні конференції без необхідності створення постійно діючої 
організації або навіть постійного секретаріату. Зрештою, впливова датська пропозиція спонукала делегації у НБСЄ домовитися про дворічну паузу після Гельсінкі, та зібратися в Белграді в 1977 р., щоб гарантувати продовження Гельсінського процесу (Rosin, 2014, p. 121).

В підсумку, після Гельсінської наради пройшло ще кілька нерегулярних зустрічей міністрів країн-учасниць: у Белграді (19771978 рр.), Мадриді (1980-1983 рр.), Стокгольмі (1984-1986 рр.) та Відні (1986-1989 рр.).

За результатом, побоювання, що СРСР перетворить зустрічі міністрів на пропагандистський форуми з підтвердження територіального статус-кво в Європі виявилися необгрунтованим. На практиці, саме кошик III (зобов'язання з прав людини) пов'язаний 3 кошиком IV (подальші зустрічі) став ключовий лейтмотивом зустрічей міністрів (Nünlist, 2008, p. 215) і фактично «трибуналом» для радянського блоку в сфері захисту прав людини, дисиденти з усієї Східної Європи вимагали, щоб їхні уряди виконували гельсінські принципи (Nünlist, Hakkarainen, 2019, p. 33).

Треба зазначити, що якщо Гельсінський заключний акт мав на меті закріпити статус-кво, то наступні документи, навпаки вітали зміни. Так, у Паризькій хартії для нової Свропи (1990р.) вказувалося, що держави-учасниці НБСС тепер готові відкрити нову главу в історії Європи: «Європа звільняється від спадщини минулого» (CSCE, Charter of Paris for a new Europe 19-21 November 1990).

Якщо свідомим вибором держав-учасниць НБСЄ на початку, у 1975 р. було не створювати постійних інституцій, то поступово Гельсінкський процес сприяв створенню так званої «безперервної ідентичності НБСЄ», яка фіксувалася у триваючих конференціях міністрів, експертних семінарах та підготовчій роботі між зустрічами, ставши своєрідним «мандрівним цирком» (Lehne, 1991, p. 10).

Як зазначає Л. Табасі основні документи, прийняті НБСЄ - ОБСЄ протягом сорокарічного періоду, відображають послідовний намір держав-учасниць, що Організація матиме політичну конституцію в міжнародних відносинах, а не юридичну конституцію відповідно до міжнародного права (Tabassi, 2019, p. 48).

Під час цих зустрічей Гельсінкський процес практично доповнювався додатковими інституціями. На Стокгольмській та Віденський (1984-1989 рр.) зустрічах було додатково створено інспекції з контролю над озброєннями та режим моніторингу прав людини, які розширили початкові цілі НБСЄ з лише декларування шляхетних 
завдань, до створення механізмів і конкретних заходів, чим також стимулювалася безперервна робота між наступними зустрічами.

В часи закінчення Холодної війни, в кінці 1980-х р., саме НБСЕ відігравала ключову роль у дискусіях щодо спільного бачення нової архітектури безпеки в Європі. У ці часи панував оптимізм і більшість політичних лідерів у Свропі були готові спільно закрити главу «Холодна війна» і розпочати «Нову еру співпраці». У Паризькій хартіï 1990 р. держави-учасниці НБСЕ оголосили, що «епоха конфронтації та поділу Свропи закінчилася» (CSCE, Charter of Paris for a new Europe 19-21 November 1990). Саме тоді НБСЄ розпочала свої перші місії зі спостереження на теренах колишнього СРСР і Югославії 3 метою обмеження збройних конфліктів що там відбувалися, або теоретично могли розпочатися.

Проте, цей оптимізм виявився передчасним. Розмови про припинення ворожнечі і створення неподільної системи європейської безпеки та нове місце в цій системі, що відводилося Росії не відповідало тому баченню, яке мала колишня наддержава, щодо свого місця у новому світі на середину 1990-х. Попередні обіцянки країн Заходу надати загальноєвропейському НБСЄ провідну роль у новій системі безпеки не були реалізовані. Зокрема, США не хотіли надавати НБСС необхідні повноваження та інструменти, необхідні для виконання такої ролі, віддаючи перевагу тому, щоб зосередити нову систему безпеки навколо НАТО. Таким чином, важливий компонент інституційного статус-кво холодної війни було збережено (Nünlist, 2017a, p. 18). Одночасно Росія намагалася забезпечити юридичну складову НБСЄ, як регіональної організації безпеки шляхом прийняття юридично обов' язкового статуту та заснування Виконавчої ради, з повноваженнями аналогічними Раді Безпеки ООН. Російські пропозиції були зрештою відхилені Заходом, коли НБСС була перетворена в ОБСС на Будапештському саміті в 1994 р. (Kropatcheva, 2015, p. 11).

В той же час, саме в рамках НБСЄ на основі Паризької хартії почали створювати нові структури та інституції, що посилювали і інституціоналізовували Нараду: постійний секретаріат, Центр запобігання конфліктів та Управління з вільних виборів. Були і інші пропозиції, так у травні 1994 р. Німеччина і Нідерланди висунули ідею «спочатку НБСЄ»: пропозиція, що НБСС діятиме як Інститут першої допомоги у вирішенні регіональних конфліктів (Zellner, 2005, p. 392). У 1993 р. Рада міністрів НБСЕ зустрілася в Римі і вирішила, що доцільно надати правовий статус, привілеї та імунітети інститутам НБСЕ, хоча і 
лише національними законодавчими засобами, а не багатостороннім договором (CSCE, 'Provisions Concerning the Legal Capacity of the CSCE Institutions and Privileges and Immunities. Legal Capacity of the CSCE Institutions ("Rome Council Decision")', CSCE/4-C/Dec.2, 1 December 1993, Decision 2, Annex 1).

У 1994 р. відбувся етапний саміт НБСС в Будапешті на якому з одного боку було ухвалено політичне рішення про перейменування НБСЄ на організацію - ОБСЄ, причому це було лише політичне перейменування без виконання юридичних процедур - ухвалення статуту. У рішенні саміту № 1 «Посилення НБСС» ясно можна побачити, що ця зміна назви не має на меті співвідноситися з більш сильною інституціоналізацією. Натомість у документі сказано: «Зміна назви з НБСС на ОБСЄ не змінює ні характеру наших зобов'язань у НБСС, ані статусу НБСС та його інституцій» (CSCE, Decision No. 1, 'Strengthening the CSCE', Budapest Document 21 December 1994). 3 іншого боку, на цьому ж саміті було відзначено, що НАТО (без Росії) буде формувати фундамент європейської безпеки, а не ОБСЄ, в якому Росія мала рівну участь. ОБСЄ створила різні інституції та механізми, але, на думку Росії, європейська безпека була побудована на основі НАТО і СС - а саме Брюссель, а не Відень, став центром нової архітектури європейської безпеки.

Поступово почала зменшуватися конструктивна співпраця Росії з ОБСЄ та перетворюватися на розчарування, роз'єднання і відсутності співучасті. Два рази розширення НАТО в 1999 і 2004 рр. остаточно сприяли відчуттю Росією іï ізоляції та маргіналізації в питаннях європейської безпеки. Замість того, щоб виступати за нову загальноєвропейську систему безпеки в рамках ОБСЄ, після 1995 р. Росія почала виступала за «Хартію європейської безпеки», яка грунтується на трьох інституційних стовпах: ОБСЕ, НАТО та ООН. Такий документ про безпеку був прийнятий на Стамбульському саміті ОБСС 1999 р., але Стамбульська хартія не досягла рівня впливу двох інших знакових документів - Гельсінського заключного акту (1975 р.) та Паризької декларації (1990р.). Більше того, теоретичні та абстрактні дискусії ОБСЄ щодо майбутнього Організації в цей час були явно затьмарені подіями в Косові, і Росія втратила довіру до ОБСС після невдалої поліцейської операції в Косові 1998- 1999 pp. (Zellner, 2005, 393).

Тим не менш, Стамбульська хартія ОБСЄ 1999 р. зміцнила оперативні можливості ОБСС шляхом досягнення згоди щодо розвитку ролі Організації в підтриманні миру і створення груп швидкого 
реагування для польових операцій. Хартія також пропонувала більш тісні зв'язки та співпрацю між ОБСС та іншими міжнародними інституціями, включаючи НАТО та СС. Проте, всупереч російським побажанням, це не передбачало інституційного перегляду. Більшість держав-учасниць ОБСЄ досі вважають, що Організація не повинна відходити від традиційного прагматизму та гнучкості, і тому традиційне правило консенсусу залишається основою для прийняття рішень у ОБСС (Ghebali, 2000, p. 23).

Наразі остання спроба реформування ОБСЄ розпочалися в Берліні з пропозиції Росії у червні 2008 р. Було запропоновано скликати загальноєвропейський саміт для обговорення нового юридично обов'язкового Договору про європейську безпеку, який би встановлював контроль над озброєннями, відмову от примусу і неподільний характер безпеки (Medvedev; Zagorski, p. 44). Ця пропозиція мала на меті радикально змінити ОБСЄ і зменшити вплив США в Свропі, надавши ОБСС юридичну компетенцію або навіть вето на рішення НАТО і СС. Це було повернення до первісної радянської ідеї європейського пакту про безпеку 1954 р. та до російської пропозицій реформи НБСЄ середини 1990-х років. Проте, серпнева 2008 р. війна в Грузії різко змінила обставини цієї дискусії. Активна участь Росії в так званому Корфуському процесі в 2009 р. була великим успіхом для ОБСС (Lynch, p. 12). Процес реформ вдалося відновити на саміт ОБСЄ в Астані у 2010 р. - першому саміт ОБСЄ за одинадцять років. У Декларації саміту в Астані підтверджено принципи НБСЄ-ОБСС, та те, що існуючі права людини не підлягають обговоренню. Проте саміт не спромігся ухвалити робочий план, в якому було б окреслено конкретні подальші кроки для досягнення «вільної, демократичної, спільної та неподільної спільноти безпеки від Ванкувера до Владивостока»; США, Грузія і Молдова наклали вето на ініціативу після того, як держави-учасниці не змогли досягти консенсусу щодо заморожених конфліктів (Zellner, 2011, p. 26).

Громіздкий процес реформування ОБСЄ продовжився і був перейменований у «Гельсінкі 40» наприкінці 2012 р. У 2013 р. почали формуватися очікування, що новий саміт ОБСС може бути скликаний до середини 2015 р., щоб відзначити укладання Гельсінського Заключного акта у 1975 р. Проте, спроба використати 40 річницю «Гельсінкі 1975» як привід стимулювати інституційні реформи ОБСС в підсумку була знищена подіями у Крим в лютому-березні 2014 р. і наступною кризою в Україні. Процес «Хельсінкі 40» тривав у 2014-2015 рр., 
і кілька робочих груп обговорили ідеї щодо зміцнення ОБСЄ. В той же час поновлене протистояння між Росією і Заходом не дозволило досягти достатнього прогресу для проведення саміту ОБСС у 2015 р. У липні 2015 р. в Гельсінкі відбулися лише короткотривалі ювілейні заходи, без представництва на високому рівні (Nünlist, 2014, p. 198-208).

Криза в Україні також послужила стимулом для більш серйозних дебатів щодо майбутньої ролі ОБСЄ. Труднощі, з якими зіткнулися спостерігачі ОБСС в Україні у березні та квітні 2014 р., коли вони працювали без привілеїв або імунітетів за відсутності укладеного Меморандуму про взаєморозуміння, ще більше підкреслили проблеми, що виникають у поточній структурі Організації. Очевидна необхідність надання міжнародної правосуб'єктності ОБСЄ стимулювала подальші заклики до реформ. Співробітники ОБСС були розгорнуті в Україні за цілих десять тижнів до того, як відбулися юридичні заходи для успішної реалізації мандату та захисту спостерігачів (Neukirch, 2015, p. 183-197).

Відкрита і неформальна робоча група з питань зміцнення правової бази ОБСЄ протягом багатьох років намагалася вирішити ці проблеми. Незважаючи на досягнення консенсусу на рівні експертів у 2007 р., проект Конвенції про міжнародну правосуб'єктність, правоздатність і привілеї та імунітети ОБСС (OSCE, Draft Convention on the International Legal Personality, Legal Capacity, and Privileges and Immunities of the OSCE, CIO.GAL/48/07/Rev.6, 23 October 2007) не був прийнятий. Деякі держави-учасниці ОБСС пов'язують запропоновану конвенцію з юридично обов' язковим Статутом ОБСЄ. Оскільки ідея такого статуту надихає до широких дебатів між членами, більш широкий проект конвенції, з якою вона пов'язана, залишається неприйнятим. Досі правовий фундамент діяльності ОБСЄ у державах-учасницях базується на римському «Рішення про правоздатність і привілеї та імунітети НБСС» 1993 р. (CSCE, 'Provisions Concerning the Legal Capacity of the CSCE Institutions and Privileges and Immunities. Legal Capacity of the CSCE Institutions ("Rome Council Decision”)', CSCE/4-C/Dec.2, 1 December 1993, Decision 2, Annex 1). Проте, це рішення виконує лише чверть держав-учасниць. Крім того, в регіоні ОБСС відсутня єдність у застосуванні правового статусу ОБСС у внутрішньому законодавстві, наскільки це стало зрозуміло з опитування держав у 2014 р. (OSCE, Report to the Ministerial Council on Strengthening the Legal Framework of the OSCE in 2014, MC.GAL/5/14/Corr.1, 3 December 2014). 
Криза в Україні у 2014 р. повернула ОБСС на ключове місце, як суттєвого учасника сучасної системи колективної безпеки - на довго забуте об'єднання ще раз підтвердило свою корисність і оперативність, фактично єдине вживши дієві кроки з стримування і контролю в рамках найбільшої кризи безпеки в Європі протягом XXI ст. Наприкінці 2014 р. швейцарське головування започаткувало нову «Панель видатних осіб» (Panel of Eminent Persons) і поставила перед експертами завдання вивчити уроки, отримані від участі ОБСЄ в врегулюванні кризи на Україні, як для Організації, так і для європейського порядку і безпеки. Фінальний звіт Панелі був опублікований у листопаді 2015 р. і запропонував запровадити потужний політичний і дипломатичний процес для подолання кризи між Росією і Заходом, зосередившись перш за все на заходах щодо зниження ризику військових інцидентів. Панель запозичала ряд ідей від «Гельсінкі $+40 »$ і рекомендувала використовувати майбутню зустріч на вищому рівні ОБСС як привід для просування зусиль з реформування (Panel of Eminent Persons, Back to Diplomacy. Vienna: OSCE 2015).

Ще один звіт Панелі було опубліковано у 2016 р. $з$ альтернативними ідеями щодо того, як відновити діалог з питань європейської безпеки (Panel of Eminent Persons, Renewing Dialogue). Вона також засвідчила відсутність зв' язку між Росією і Заходом, стверджуючи, що це може призвести до небезпечних помилок і прорахунків під час кризової ситуації. Як засіб для визначення розбіжностей і сфер зближення між двома сторонами, у звіті інноваційно запропоновано оновлення стратегії ОБСС ухваленої в грудні 2003 р. «Стратегія подолання загроз безпеці і стабільності у XXI столітті» (OSCE, Strategy to Address Threats to Security and Stability in the Twenty-First Century, 2 December 2003). Під час виконання цього завдання запропоновано підкреслити схожість держав-учасниць, а також необхідність багатостороннього співробітництва у вирішенні проблем національної безпеки. Хоч у доповіді 2016 р. наголошувалося, що відновлення діалогу з Росією без значного прогресу у виконанні Мінського протоколу (2014р.) ризикує сприйнятися, як повернення до звичайних відносин, або навіть як нагороду за так звану «погану поведінку», стверджувалося, що саме в часи кризи діалог найбільш необхідний. Розмовляти тільки з друзями - це погана дипломатія.

На думку ОБСЄ повернення до вибіркової, на основі спільних інтересів, співпраці з Росією поступово сприятиме зміцненню довіри як основи для більш стійкого співробітництва (Nünlist, Hakkarainen, 
2019, р. 34). Перший крок у цьому напрямку було здійснено після відновленням контролю за звичайними озброєннями в Свропі у серпні 2016 р. Спочатку було ініційовано головуючою Німеччиною в рамках ОБСЄ неформальний, але структурований діалог про сприйняття загроз та інтереси спільної політики безпеки, про поточні та майбутні виклики та ризики (Nünlist, 2017b, p. 14). У квітні 2017 р. розпочалося обговорення поглядів на існуючі загрози між високопоставленими посадовими особами держав-учасниць ОБСЄ в Відні. Мета полягає у вирішенні викликів у ширшій політико-військовій сфері та вивченні можливостей подолання розбіжностей. Окрім сприяння кращому розумінню сприйняття загроз, очікується, що майбутні зустрічі стосуються останніх подій у військових доктринах і тенденціях (OSCE, OSCE to Explore Common Ground on Current and Future Security Challenges, Press Release, 7 April 2017).

Комунікація важлива для деескалації, а діалог є важливою передумовою розрядки. Більше того, необхідно підкреслити, що діалог не $є$ синонімом умиротворення, а спробою вислухати та зрозуміти іншу сторону не є синонімом прийняття ії аргументів. Здається, що як НБСЄ під час холодної війни, так і ОБСЄ сьогодні представляється найбільш підходящим форумом для безперервного вивчення практичних способів ретельного управління поточною нестабільною конфронтацією з Росією, при цьому твердо захищаючи західні інтереси та цінності.

На нашу думку можна виділити такі етапи в історії становлення НБСЄ/ОБСЄ. 1. Становлення НБСЄ від підготовчої конференції до Гельсінського заключного акту. 2. Існування НБСС як постійно діючої міжнародної конференції. 3. Зміна назви на ОБСС і поступове наповнення інституційною структурою. 4. Спроби наділити ОБСЄ міжнародною правосуб'єктністю.

\section{References:}

Rey M. P. (2008). The USSR and the Helsinki Process, 1969-75: Optimism, Doubt, or Defiance? Origins of the European Security System: The Helsinki Process Revisited, 1965-75 / Andreas Wenger, Vojtech Mastny and Christian Nünlist eds. London: Routledge, 65-81.

Nünlist C. (2008). Expanding the East-West Dialog beyond the Bloc Division: The Neutrals as Negotiators and Mediators. Origins of the European Security System: The Helsinki Process Revisited, 1965-75 / Andreas Wenger, Vojtech Mastny and Christian Nünlist eds. London: Routledge, 201-221. 
Rosin P. (2014). Die Schweiz im KSZE-Prozess 1972-1983: Einfluss durch Neutralität [Switzerland in the CSCE process 1972-1983: Influence through neutrality. Munich: Oldenbourg]. Munich: Oldenbourg. [in German].

Nünlist C., Hakkarainen P. (2019). Political Dynamics and Institutional Reforms in the OSCE. The Legal Framework of The OSCE / Edt. by Mateja Steinbrück Platise, Carolyn Moser, Anne Peters. Cambridge: University Printing House, Cambridge, 29-48.

CSCE, Charter of Paris for a new Europe 19-21 November 1990. <https:// www.osce.org/mc/39516?download=true>.

Lehne S. (1991). The CSCE in the 1990s: Common European House or Potemkin Village? Vienna: Braumüller.

Tabassi L. (2019). The Role of the Organisation in Asserting Legal Personality: the Position of the OSCE Secretariat on the OSCE's Legal Status. The Legal Framework of The OSCE / Edt. by Mateja Steinbrück Platise, Carolyn Moser, Anne Peters. Cambridge: University Printing House, Cambridge, 48-82.

Nünlist C. (2017). Contested History: Rebuilding Trust in European Security. Strategic Trends, 9-32.

Kropatcheva E. (2015). The Evolution of Russia's OSCE Policy: From the Promises of the Helsinki Final Act to the Ukrainian Crisis. Journal of Contemporary European Studies, Vol. 23, № 1, 6-24.

ZellnerW. (2005). Russia and the OSCE: From High Hopes to Disillusionment. Cambridge Review of International Affairs, Vol. 18, № 3, 389-402.

CSCE, 'Provisions Concerning the Legal Capacity of the CSCE Institutions and Privileges and Immunities. Legal Capacity of the CSCE Institutions ("Rome Council Decision")', CSCE/4-C/Dec.2, 1 December 1993, Decision 2, Annex 1. <www.osce.org/mc/40401?download=true>.

CSCE, Decision No. 1, 'Strengthening the CSCE', Budapest Document 21 December 1994. <www.osce.org/mc/39554?download=true>, 22.

Ghebali V.-Y. (2000). The OSCEs Istanbul Charter for European Security. NATO Review, Vol. 48, № 1, 23-26.

Medvedev D. 'European Security Treaty'. < http:/ / en.kremlin.ru/events/ president/news/6152>.

Zagorski A. The Russian Proposal for a Treaty on European Security: From the Medvedev Initiative to the Corfu Process. OSCE Yearbook 2009. Baden-Baden: Nomos Verlagsgesellschaft, 43-59. 
Lynch D. The State of the OSCE. The EU-Russia Centre Review: Russia, the OSCE and European Security, № 12, 5-13.

Zellner W. (2011). Das OSZE-Gipfeltreffen in Astana im Jahr 2010 [The OSCE Summit in Astana in 2010]. OSCE Yearbook 2010. Baden-Baden: Nomos Verlagsgesellschaft [OSCE Yearbook 2010. Baden-Baden: Nomos Publishing Company], 23-31. [in German].

Nünlist C. (2014). Helsinki +40 in the Historical Context. Security and Human Rights, Vol. 25, 198-209.

Neukirch C. (2015). The Special Monitoring Mission to Ukraine: Operational Challenges and New Horizons. OSCE Yearbook 2014. Baden-Baden: Nomos Verlagsgesellschaft, 183-197.

OSCE, Draft Convention on the International Legal Personality, Legal Capacity, and Privileges and Immunities of the OSCE, CIO.GAL/48/07/ Rev.6, 23 October 2007.

OSCE, Report to the Ministerial Council on Strengthening the Legal Framework of the OSCE in 2014, MC.GAL/5/14/Corr.1, 3 December 2014.

Panel of Eminent Persons, Back to Diplomacy. Vienna: OSCE 2015.

Panel of Eminent Persons, Renewing Dialogue.

OSCE, Strategy to Address Threats to Security and Stability in the Twenty-First Century, 2 December 2003. <www.osce.org/ $\mathrm{mc} / 17504$ ?download=true $>$.

Nünlist C. (2017). The OSCE and the Future of European Security. CSS Analyses in Security Policy, № 202, 2-13.

OSCE, OSCE to Explore Common Ground on Current and Future Security Challenges, Press Release, 7 April 2017. <www.osce.org/ chairmanship/310481>.

\section{Анотація}

Дубовик В. Б. Політичні і міжнародно-правові етапи історії становлення ОБСЕ. - Стаття.

Стаття присвячена вивченню історії становлення Організації з безпеки та співробітництва в Європі (ОБСЄ) у історичному, політикодипломатичному та міжнародно-правовому аспектах. Історія становлення ОБСЕ саме на поєднанні ици аспектів стає гармонічною та зрозумілою. $Є$ неможливим досліджувати міжнародно-правові аспекти у відриві від дипломатичних оскільки за своєю суттю ОБСє подовжує залишатися обєднанням 
держав з невизначеним чітко міжнародно-правовим статусом. ОБСЕ на сучасному етапі походить з загальноєвропейської дипломатичної конференції - НБСЄ, щзо з часом стала постійно діючою. Поступово вона змінювала свою назву та розширювала наявні механізми реагування та управління, проте, так і не змогла здобути статусу міжнародної міжурядової організації. Причини изього досліджені у нашій статті. Своєю чергою в історії становлення НБСЕ/ОБСС можна виділити такі етапи: 1. Становлення НБСЄ від підготовчої конференції до Гельсінського заключного акту. 2. Існування НБСС як постійно діючої міжнародної конференції. З. Зміна назви на ОБСЄ і поступове наповнення інституиіийною структурою. 4. Спроби наділити ОБСЕ міжнародною правосуб'єктністю.

Ключові слова: Організачія з безпеки та співробітництва в Європі, право міжнародних організацій, міжнародні конферениіі, міжнародний доrobip, США. 